\title{
Home range and movements of Amazon river dolphins Inia geoffrensis in the Amazon and Orinoco river basins
}

\author{
Federico Mosquera-Guerra ${ }^{1,2, *}$, Fernando Trujillo ${ }^{1}$, Marcelo Oliveira-da-Costa ${ }^{3}$, \\ Miriam Marmontel ${ }^{4}$, Paul André Van Damme ${ }^{5}$, Nicole Franco ${ }^{1}$, Leslie Córdova ${ }^{5}$, \\ Elizabeth Campbell ${ }^{6,7,8}$, Joanna Alfaro-Shigueto ${ }^{6,7,8}$, José Luis Mena ${ }^{9}$, \\ Jeffrey C. Mangel ${ }^{6,7,8}$, José Saulo Usma Oviedo ${ }^{3}$, Juan D. Carvajal-Castro ${ }^{10,11}$, \\ Hugo Mantilla-Meluk ${ }^{12,13}$, Dolors Armenteras-Pascual ${ }^{2}$ \\ ${ }^{1}$ Fundación Omacha, 111211 Bogotá, D.C., Colombia \\ ${ }^{2}$ Grupo de Ecología del Paisaje y Modelación de Ecosistemas-ECOLMOD, Departamento de Biología, \\ Universidad Nacional de Colombia, 111321 Bogotá, D.C., Colombia \\ ${ }^{3}$ World Wildlife Fund (WWF) - Brazil, Colombia, and Peru, Rue Mauverney 28, 1196 Gland, Switzerland \\ ${ }^{4}$ Instituto de Desenvolvimento Sustentável Mamirauá, 69.553-225 Tefé (AM), Brazil \\ ${ }^{5}$ Faunagua, 31001 Sacaba-Cochabamba, Bolivia \\ ${ }^{6}$ ProDelphinus, 15074 Lima, Peru \\ ${ }^{7}$ School of BioSciences, University of Exeter, Penryn, Cornwall TR10 9EZ, UK \\ ${ }^{8}$ Carrera de Biología Marina, Universidad Cientifíca del Sur, 15067 Lima, Peru \\ ${ }^{9}$ Museo de Historia Natural Vera Alleman Haeghebaert, Universidad Ricardo Palma, 1801 Lima, Peru \\ ${ }^{10}$ Grupo de Investigación en Evolución, Ecología y Conservación (EECO), Programa de Biología, Universidad del Quindío, \\ 630004 Armenia, Colombia \\ ${ }^{11}$ Department of Biological Sciences, St. John's University, 11366 Queens, NY, USA \\ ${ }^{12}$ Grupo de Investigación en Desarrollo y Estudio del Recurso Hídrico y el Ambiente (CIDERA), Programa de Biología, \\ Universidad del Quindío, 630004 Armenia, Colombia \\ ${ }^{13}$ Centro de Estudios de Alta Montaña, Universidad del Quindío, 630004 Armenia, Colombia
}

\begin{abstract}
Studying the variables that describe the spatial ecology of threatened species allows us to identify and prioritize areas that are critical for species conservation. To estimate the home range and core area of the Endangered (EN) Amazon river dolphin Inia geoffrensis, 23 individuals $\left(60,17 o^{7}\right)$ were tagged during the rising water period in the Amazon and Orinoco river basins between 2017 and 2018. The satellite tracking period ranged from 24 to $336 \mathrm{~d}$ (mean $\pm \mathrm{SE}=107 \pm$ $15.7 \mathrm{~d})$, and river dolphin movements ranged from 7.5 to $298 \mathrm{~km}(58 \pm 13.4 \mathrm{~km})$. Kernel density estimates were used to determine minimum home ranges at $95 \%\left(\mathrm{~K}_{95}=6.2\right.$ to $233.9 \mathrm{~km}^{2}$; mean $=$ $\left.59 \pm 13.5 \mathrm{~km}^{2}\right)$ and core areas at $50 \%\left(\mathrm{~K}_{50}=0.6\right.$ to $54.9 \mathrm{~km}^{2}$; mean $\left.=9 \pm 2.6 \mathrm{~km}^{2}\right)$. Protected areas accounted for $45 \%$ of the $\mathrm{K}_{50}$ estimated core area. We observed dolphin individuals crossing country borders between Colombia and Peru in the Amazon basin, and between Colombia and Venezuela in the Orinoco basin. Satellite tracking allowed us to determine the different uses of riverine habitat types: main rivers (channels and bays, $52 \%$ of recorded locations), confluences $(32 \%)$, lagoons $(9.6 \%)$, and tributaries $(6.2 \%)$. Satellite monitoring allowed us to better understand the ecological preferences of the species and demonstrated the importance of maintaining aquatic landscape heterogeneity and spatial connectivity for effective river dolphin conservation.
\end{abstract}

KEY WORDS: South America · Satellite telemetry $\cdot$ Kernel density $\cdot$ Cetaceans $\cdot$ Neotropical rivers · Conservation $\cdot$ Protected areas $\cdot$ Transboundary

${ }^{*}$ Corresponding author:

federico.mosqueraguerra@gmail.com
() The authors 2021. Open Access under Creative Commons by Attribution Licence. Use, distribution and reproduction are unrestricted. Authors and original publication must be credited. 


\section{INTRODUCTION}

The home range of animals is an important spatial ecological variable operating as a proxy for a species' biological needs (Kenward 2001, Hemson et al. 2005), and its key resource supply (Flores \& Bazzalo 2004). Among other biological variables, the home range of some cetacean species is related to (1) animal body mass (Harestad \& Bunnel 1979, Swihart et al. 1988, Gubbins 2002); (2) sex and age (Wells 1991); (3) the density of conspecifics; and (4) the distribution of mates (Ostfeld 1990). In addition, home ranges are good predictors of productivity and habitat heterogeneity, enabling ecological comparisons among geographically distinct populations (Ballance 1992, Gubbins 2002, Ouellette \& Cardille 2011).

Areas within home ranges are not occupied homogeneously (Dixon \& Chapman 1980, Samuel et al. 1985); some of the areas that are used more frequently are called 'core areas', and are often associated with greater resource density (Samuel et al. 1985, Powell 2000, Oshima et al. 2010). When identifying the extent of home ranges and, in particular, core areas, it is also essential to identify a species' critical habitats to help guide population management (Ingram \& Rogan 2002, Seminoff et al. 2002, Rayment et al. 2009) and design protected areas.

There are several methodological approaches that can be used to estimate home ranges and core areas. From location data points it is possible to produce utility distributions (UD) that describe the differences in the intensity of home range use (Powell 2000, Oshima et al. 2010). Kernel density estimators are useful for quantifying the intensity of habitat use (Worton 1989, Ouellette \& Cardille 2011) and are among the most robust and widely applied non-parametric statistical methods for estimating the probability of the occurrence of individuals (Seaman \& Powell 1996, Seaman et al. 1999, Powell 2000, Oshima et al. 2010).

Spatial ecological assessments for aquatic species have been conducted for a number of cetaceans, including harbor porpoise Phocoena phocoena (Sveegaard et al. 2011), Hector's dolphin Cephalorhynchus hectori (Rayment et al. 2009), common bottlenose dolphin Tursiops truncatus (Defran et al. 1999, Gubbins 2002, Wells et al. 2017), franciscana dolphin Pontoporia blainvillei (Bordino et al. 2008), Guiana dolphin Sotalia guianensis (Flores \& Bazzalo 2004, Rossi-Santos et al. 2006, Azevedo et al. 2007, Wedekin et al. 2007, Oshima et al. 2010), and Amazon river dolphin (Martin \& da Silva 1998, 2004a). This last study was conducted in the Mamirauá Sustainable
Development Reserve in Brazil and represents the first long-term home range study of adult river dolphins $(\mathrm{N}=53)$ using VHF radio transmitters.

The dynamic nature of hydrological systems presents a considerable challenge for numerically determining the spatial ecological variables of aquatic organisms, especially due to the logistical constraints related to individual detection and identification. The latter is particularly true for Amazon river dolphins, which are highly mobile top predators able to cover long distances (hundreds of kilometers) in relatively short periods (days) with a possible differential use of habitat by males and females (Martin \& da Silva 1998, 2004a, Trujillo 2000, Gómez-Salazar et al. 2012c, Mosquera-Guerra et al. 2018).

Amazon river dolphins are subdivided into 2 subspecies: Inia geoffrensis geoffrensis that are distributed across the Amazon (da Silva 2002) and Orinoco basins (Herrera et al. 2017), and I. g. boliviensis, found along the Mamoré, Iténez, and Madeira rivers (AliagaRossel 2002, Aliaga-Rossel et al. 2006, Gravena et al. 2014). Considered as Endangered (da Silva et al. 2018), Amazon river dolphins are among the most threatened aquatic mammals. Their populations are declining due to (1) deliberate killing and bycatch (Trujillo et al. 2010, Mintzer et al. 2016, da Silva et al. 2018); (2) habitat degradation through timber exploitation, agricultural expansion, and gold mining; (3) climate change (Mosquera-Guerra et al. 2015, 2019, 2020); and (4) the construction of hydropower dams, primarily in Brazil (Anderson et al. 2018). To date, there are 175 dams that are operating or are under construction in the Amazon basin, as well as at least 428 more planned over the next $30 \mathrm{yr}$, including 21 large dams (Forsberg et al. 2017, Latrubesse et al. 2017, Anderson et al. 2018, Almeida et al. 2020). Dams have transformed $16.4 \%$ of the distribution of I. g. geoffrensis in the Amazon basin, 22.9\% in the Orinoco basin, and $54.9 \%$ in the Tocantins-Araguaia hydrographic complex (Mosquera-Guerra et al. 2018). Currently, 2 dams exist within the range of $I . \mathrm{g}$. boliviensis in the Madeira River (Gravena et al. 2014, 2015).

The intensity and scale of threats to Inia populations in South America require urgent action to quantitatively determine the spatial requirements of these cetaceans in different ecosystems throughout their range. In this study, we used satellite tracking to collect quantitative spatial information on Amazon river dolphins across 5 rivers in the Amazon and Orinoco basins with special attention to an assessment of home ranges and core areas, use of protected areas, and transboundary movements. 


\section{MATERIALS AND METHODS}

\subsection{Study area}

This study was conducted from October 2017 to December 2018 across 5 rivers in the Amazon and Orinoco basins. Captures were made along transects: (1) from the lower Juruena River sub-basin in Brazil and the Cururu River, including its confluence with the Teles Pires River in the Tapajós River basin; (2) in the main channel of the San Martín River in Bolivia, from its confluence with the San Joaquin River to the border between Beni and Santa Cruz provinces; (3) from the confluence of the Atacuari and the Amazon River in Colombia to the Zaragoza Creek, including the Tarapoto wetland complex, and the confluence of the Loretoyacu and the Amazon rivers; (4) from the mid-basin of the Orinoco River in Colombia, including its confluences with the Bita and Meta rivers; and (5) from the confluence of the Huallaga and Marañon rivers in Peru to the confluence of the Ucayali and the Marañón rivers, including the confluence with the Marañón and Tigre rivers (Fig. 1).

Ecological and threat variables considered here included: (1) biogeographic influence and water types, i.e. black, clear, white, and mixed (Sioli 1984, Junk \& Furch 1993, Hoorn \& Wesselingh 2010); (2) habitat types, i.e. main rivers (channels and bays) with várzea (forests flooded by whitewater), confluences, tributaries, and lagoons with igapó (Amazon forests flooded by blackwaters) (Trujillo 2000, Martin \& da Silva 2004b, Gómez-Salazar et al. 2012c); (3) proximity to protected areas, i.e. national and regional natural parks, reserves, and Ramsar sites; and (4) threats to river dolphin populations, i.e. gold mining, dams, and by-catch (Table 1).

\subsection{Dolphin capture protocol and measurement recording}

Only adult individuals were selected for tagging, and their age class was estimated based on body length, following the methods of da Silva (2009) and Martin \& da Silva (2018), and avoiding females with calves (see Table 2).

Field work was conducted in locations previously investigated by Gómez-Salazar et al. (2012a, 2012b), Mosquera-Guerra et al. (2019), and Trujillo et al. (2019) in the Colombian and Peruvian Amazon and the Orinoco River in Colombia (conservation and abundance estimates); Pavanato et al. (2016) in the Tapajos River, Brazil (conservation and abundance estimates); and Aliaga-Rossel \& Guizada Duran (2020) in San Martín and Iténez, Bolivia (abundance estimates).

Capture locations were chosen based on accessibility, river width, and water depth. We implemented 2 different capture techniques depending on the river width. The first technique was employed in water courses less than $300 \mathrm{~m}$ wide. Two small boats (6-8 m length, propelled by 20-40 hp outboard motors) were used to set two $300 \mathrm{~m}$ nets with $5 \mathrm{~cm}$ mesh size. The first net was placed $100 \mathrm{~m}$ upstream and $100 \mathrm{~m}$ downstream from the observed target group. Fishermen walking along the banks of the river then slowly moved the upstream net toward the dolphin group. Once the net had been moved $50 \mathrm{~m}$ downstream, a third net was deployed by a boat without an outboard motor to avoid scaring the animals. The aim of this operation was to steer the individuals in the direction of the riverbank. The second technique was used in water courses wider than $300 \mathrm{~m}$. One end of the net was fixed to a $3 \mathrm{~m}$ pole held by a fisherman close to the riverbank. From this fixed point, the net was rapidly extended around the target dolphin group by a motorboat, forming a halfmoon with a radius of $100 \mathrm{~m}$ upstream. As dolphins were caught in the nets, they were immediately untangled and carefully transported to the riverbank or to a processing platform in a motorboat.

As part of our protocol, a veterinary team was present throughout the capture procedure to monitor the health of the animals according to cardiac and respiratory rates. The whole procedure lasted around 10 to $45 \mathrm{~min}$. There was no evidence that individuals experienced excessive stress. No increase in heart and respiratory rates, or sudden movements of head or caudal fins were noted, as have been previously documented as signs of stress (Martin et al. 2006). In the event of excessive stress, our safety protocol required that the capture operation would immediately be halted and the dolphin released.

\subsection{Tag specification, permissions, and method of attachment}

The tags used were SPOT-299A and SPOT6-F single-point fin mounted satellite tags (Wildlife Computers), $20.8 \mathrm{~cm}$ long, $2.0 \mathrm{~cm}$ wide, $2.5 \mathrm{~cm}$ high, and weighing $62 \mathrm{~g}$. The tags had an $18 \mathrm{~cm}$ long flexible antenna, plastic wings, and a $6.5 \times 2.0 \mathrm{~cm}$ tail. The tags were positioned on each side of the trailing edge of the dorsal fin, with a matching $0.8 \mathrm{~cm}$ diameter hole in each for attaching the tag $3.5 \mathrm{~cm}$ anterior to 

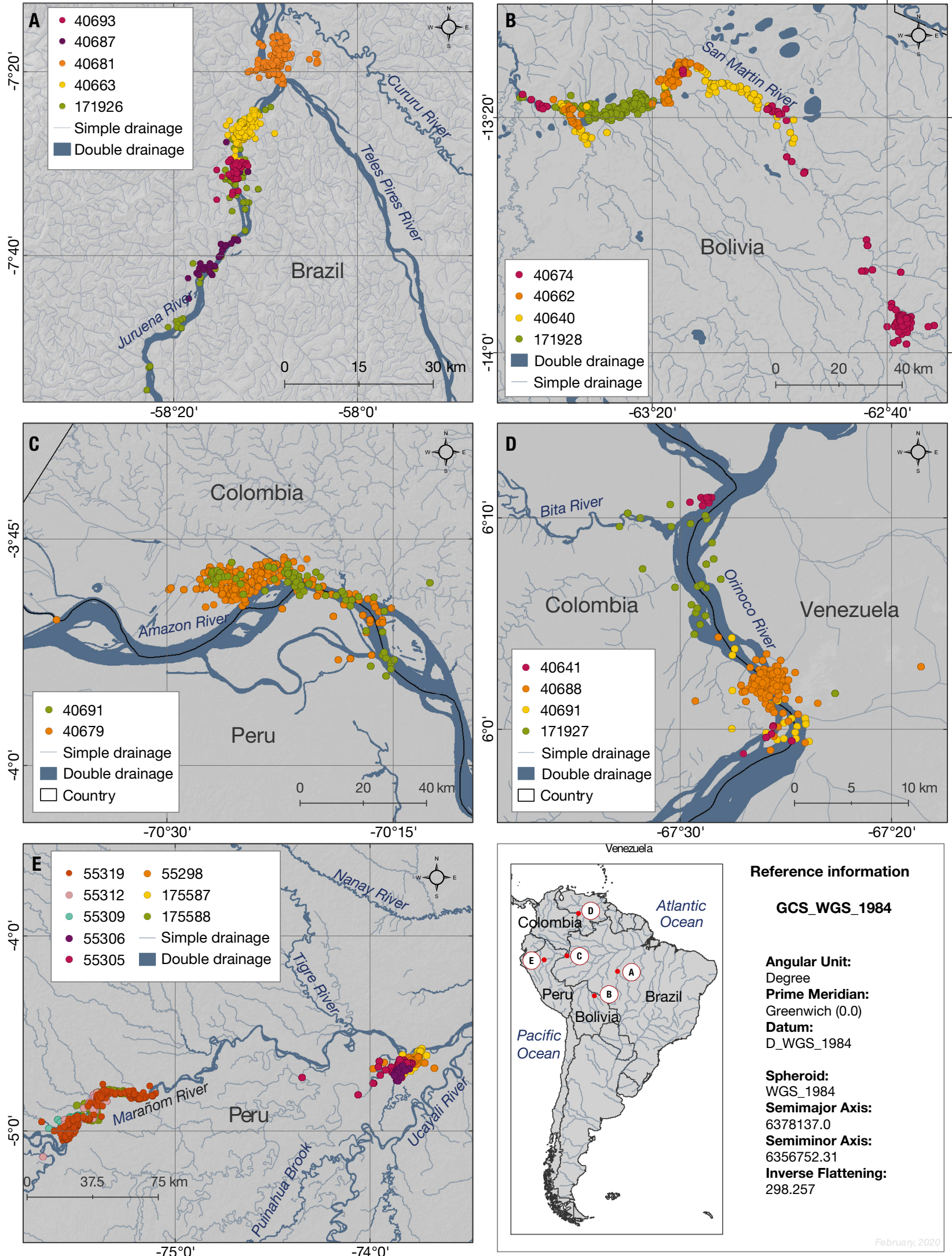

Reference information

GCS_WGS_1984

Angular Unit:

Degree

Prime Meridian:

Greenwich (0.0)

Datum:

D WGS 1984

Spheroid:

WGS_1984

Semimajor Axis:

6378137.0

Semiminor Axis:

6356752.31

Inverse Flattening:

298.257

Fig. 1. Satellite-linked locations for the 23 Amazon river dolphins tagged in the Amazon and Orinoco basins. Rivers: (A) Juruena, Brazil, (B) San Martín, Bolivia, (C) Amazon, Colombia, (D) Orinoco, Colombia, and (E) Marañón, Peru. Simple drainage: minor water bodies, generally small tributaries; double drainage: main rivers 
Table 1. Information on Amazon river dolphins Inia geoffrensis tagged with satellite-linked transmitters in the Amazon and Orinoco basins, 2017-2018. ọ: female; ơ⿱: male

\begin{tabular}{|c|c|c|c|c|c|c|c|}
\hline Country & Basin & Subbasin & Rivers & $\begin{array}{c}\text { Biogeographic influence of } \\
\text { the basin }\end{array}$ & $\begin{array}{l}\text { Water } \\
\text { type }\end{array}$ & Taxon & $\begin{array}{l}\text { Number } \\
\text { and sex }\end{array}$ \\
\hline Brazil $^{\mathrm{a}}$ & Amazon & Tapajós & Juruena & Amazon-Brazilian Shield & Clear & I. g. geoffrensis & $1 \%, 40^{7}$ \\
\hline Colombia $^{b}$ & Amazon & Amazon & Amazon & Andean-Amazon & Mixed & I. g. geoffrensis & 10 \\
\hline Bolivia $^{\mathrm{a}}$ & Amazon & Iténez & San Martín & Amazon-Brazilian Shield & Clear & I. g. boliviensis & $10,30^{7}$ \\
\hline Colombia & Orinoco & Orinoco & Orinoco & Orinoco-Guiana Shield & White & I. g. geoffrensis & $2 o, 20^{7}$ \\
\hline Peru $^{\mathrm{a}}$ & Amazon & Marañón & Marañón & Andean-Amazon & White & I. g. geoffrensis & $10,70^{7}$ \\
\hline Colombia $^{\mathrm{b}}$ & Amazon & Amazon & Amazon & Andean-Amazon & Mixed & I. g. geoffrensis & $10^{7}$ \\
\hline
\end{tabular}

the fin's trailing edge, following Balmer et al. (2011, 2014) and Wells et al. (2013, 2017). The tags were programmed for continuous transmission (24 h), up to 250 times a day, to an ARGOS satellite constellation, providing location and tag status data, and yielding up to 240 tracking days based on battery life. Satellite tagging was conducted under research permits for each country (Bolivia: DGBAP/MEG No. 0515/2017; Brazil: SISBIO 60171-1; Colombia: No. DTA 0898/2018; Peru: RD 515-2018 PRODUCE, RJ 003-2018).

\subsection{Location data and filtering}

Estimates of the tagged Amazon river dolphin locations were received and processed by the ARGOS Data Collection and Location System and downloaded from CLS-ARGOS. ARGOS uses multiple, polar-orbiting satellites to receive data from tags, and transmits this data to ground-based processing centers. Tag locations were calculated using the Doppler effect on transmission frequency and a location-processing algorithm (Collecte Localization Satellites [CLS] 2011).

Locations were classified by the ARGOS system into 1 of 6 location classes (LCs) based on the level of accuracy measured in kilometers of uncertainty for latitude and longitude. ARGOS classifies location quality relative to an estimated error radius in the following location classes: 3 (accurate to $<250 \mathrm{~m}$ ), 2 (accurate to 250-500 m), 1 (accurate to 500-1500 m), and A and B (1-2 messages received but no accuracy estimation). In our study, we used only the most accurate data, LCs 3 and 2, after filtering the data with SAS-routine and ARGOS-Filter (Witt et al. 2010, Wells et al. 2017, Dolton et al. 2020). Data with low accuracy, LC1 (500-1500 m), and data in classes A and $B$, with no accuracy estimations, were not used in our analysis.

\subsection{Kernel density estimate and movement}

A kernel density estimate at a $95 \%$ probability UD $\left(\mathrm{K}_{95}\right)$ was used to calculate home range, whereas a kernel density estimate at a $50 \%$ probability UD $\left(\mathrm{K}_{50}\right)$ was used to measure the core area. Home ranges calculated using the kernel density estimator (KDE) were used to estimate UDs. In addition, the longest distance between 2 locations was estimated following Gubbins (2002), Seminoff et al. (2002), Flores \& Bazzalo (2004), Rayment et al. (2009), Oshima et al. (2010), and Wells et al. (2017). A UD represents the probability of finding a given individual in a certain place and describes the use of space (White \& Garrott 1990, Wells et al. 2017). It also identifies areas of intense use (Powell 2000, Wells et al. 2017). Mapping was performed using the Geostatistical Analyst and Spatial Analyst extensions in ESRI ArcGIS version 10.2.2. (ESRI 2014), and the smoothing parameter of the Beizer interpolation was used following Worton (1989), MacLeod (2013), Wells et al. (2017), and Dolton et al. (2020).

River dolphin tagging was carried out during the rising water period for Colombia and Peru, and during the maximum water levels for Brazil and Bolivia. River depth in our sampling locations ranged from $8 \mathrm{~m}$ in Juruena to $44 \mathrm{~m}$ in the Amazon (Goulding et al. 2003). Permanent islands and shoreline areas were subtracted from the home range and core area calculations, based upon satellite images for the study period (Copernicus Sentinel 2020). We followed the habitat types proposed by Gómez-Salazar et al. (2012a). The main river, confluences, tributaries, and lagoons were delimited in satellite images downloaded from the Copernicus Sentinel platform, and processed through the Geostatistical Analyst and Spatial Analyst extensions in ESRI ArcGIS version 10.2.2 (ESRI 2014). The number of locations (95\% significance level) per habitat type were quantified 
and classified using the ArcGIS version 10.2.2 software tools (ESRI 2014, Copernicus Sentinel 2020). Mean values \pm SE are reported throughout this paper and were calculated using RStudio version 1.1.383 (R Studio Team 2014), running R version 3.5.2 (R Core Team 2017).

\section{RESULTS}

\subsection{Tracking effort}

Satellite tag-linked locations were analyzed for 23 adult Amazon river dolphins $\left(6 \%, 17 \sigma^{7}\right)$ between 2017 and 2018. The transmitters were installed on individuals in the (1) Juruena River in Brazil $\left(\mathrm{n}=5,10,4 \mathrm{o}^{\mathbf{T}}\right)$; (2) San Martín River in Bolivia $(\mathrm{n}=4,1 \text { o, 30 })_{\text {; }}$ (3) Amazon River in Colombia ( $\left.\mathrm{n}=2,1 \%, 10^{7}\right)$; (4) Orinoco River in Colombia ( $\left.\mathrm{n}=4,2 \circ, 2 \sigma^{7}\right)$; and (5) Ucayali River in Peru $\left(n=8,1 \%, 7 \sigma^{\prime}\right)$. The body length of tracked individuals ranged from 159 to $227 \mathrm{~cm}$ (mean $190 \pm 3.7 \mathrm{~cm}$ ) and their weight from 49 to $200 \mathrm{~kg}$ (mean $94 \pm 7.4 \mathrm{~kg}$ ). The number of satellite locations with accuracy classes of 2 and 3 ranged from 96 to 1697 (mean $626 \pm 103$ locations) and the tracking duration ranged from 24 to $336 \mathrm{~d}$ (mean 107 $\pm 16 \mathrm{~d}_{\text {; }}$ Table 2).

\subsection{Ranging patterns}

The longest total distance traveled by a tagged individual in our study was $297.9 \mathrm{~km}$, recorded by an Inia geoffrensis boliviensis male in the San Martín River, Bolivia. The shortest distance recorded was $7.5 \mathrm{~km}$ by an I. g. geoffrensis male in the Juruena River in Brazil (Table 2). The total and daily movements (ranges, mean, and SE) for all tagged individuals are reported in Table 3 . The tagged dolphins made transnational movements, with 1 I. g. geoffrensis individual crossing between Colombia and Peru $(36.2 \mathrm{~km})$ along the Amazon River and 3 I. g. geoffrensis individuals crossing between Colombia and Venezuela $(51.8 \mathrm{~km})$ through the Orinoco River basin. Since the transmission of satellite data was set at intervals, it was difficult to determine how many times these transboundary movements occurred.

The mean numbers of satellite-tracking locations for all individuals in each habitat type were (1) confluences: $35.0 \pm 11.3$ in the Orinoco River, Colombia to $299.5 \pm 68.5$ in the Marañón River, Peru; (2) main river: $100.5 \pm 32.5$ in the Amazon River, Colombia to $438.1 \pm 120.8$ in the Marañón River, Peru; (3) lagoons:
$10.8 \pm 10.0$ in the Marañón River, Peru to $588.0 \pm$ 425.0 in the Amazon River, Colombia; and (4) tributaries: $11.7 \pm 1.8$ in the Orinoco River, Colombia to $67.0 \pm 15.1$ in the Juruena River, Brazil (Table 4).

\subsection{Home range size}

A minimum home range was measured using only locations with an estimated error radius of $<500 \mathrm{~m}$. The minimum home range $\left(\mathrm{K}_{95}\right)$ estimates varied from 12.1-27.9 km² (Juruena River, Brazil) to 60.5$233.9 \mathrm{~km}^{2}$ (San Martín River, Bolivia), while the core area $\left(\mathrm{K}_{50}\right)$ estimates ranged from $0.6-9.1 \mathrm{~km}^{2}$ (Juruena River, Brazil) to $3.7-54.9 \mathrm{~km}^{2}$ (San Martín River, Bolivia; Fig. 2, Table 5).

The use of protected areas was calculated based only on the core areas of the monitored river dolphins. These proportions ranged from $10.3 \%$ (Orinoco River, Colombia) to $79 \%$ (San Martín River, Bolivia). Intermediate values were recorded for the Juruena River, Brazil (66.5\%), Amazon River, Colombia (51.6\%), and Marañón River, Peru (19.8\%).

\section{DISCUSSION}

The spatial ecology of Amazon river dolphins (including estimates of home ranges, movements, and habitat use) has been assessed with a variety of methods, such as: (1) strip-width transects (McGuire \& Winemiller 1998, Aliaga-Rossel 2002, Martin \& da Silva 2004a, Denkinger 2010); (2) photo-identification (McGuire \& Henningsen 2007); (3) capturerecapture (Martin \& da Silva 2004a, Mintzer et al. 2016); and (4) tagging with VHF radio transmitters (Martin \& da Silva 1998, 2004b). Nevertheless, there are still several unanswered questions regarding the habitat selection of dolphins. The use of satellite devices in this study allowed us to estimate the minimum home ranges, core areas, and movements of tracked individuals, providing more accurate and higher resolution versions of these variables. It also gave us the opportunity to address questions regarding habitat selection by Amazon river dolphins.

\subsection{Ranging patterns and habitat heterogeneity}

The movement values reported in our study (Tables $2 \& 3$ ) are comparable to those of Martin \& da Silva $(1998,2004 b)$, who reported that the maximum 


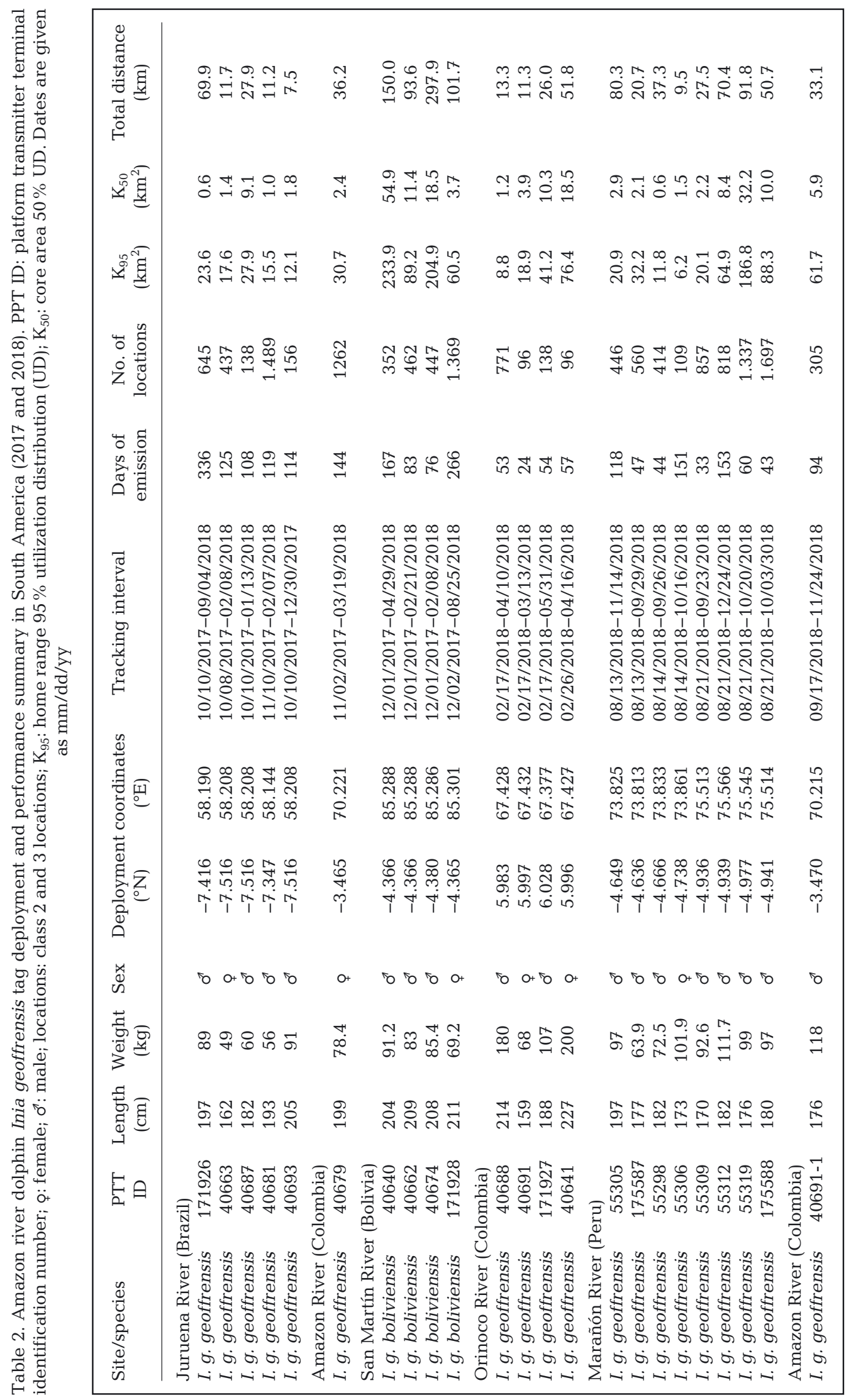


Table 3. Total and daily distances traveled and the habitats used. n: number of Amazon river dolphins tagged

\begin{tabular}{|c|c|c|c|c|}
\hline Rivers & $\mathrm{n}$ & Habitats used & $\begin{array}{l}\text { Total distance traveled }(\mathrm{km}) \\
\text { range }(\text { mean } \pm \mathrm{SE})\end{array}$ & $\begin{array}{l}\text { Daily movement }(\mathrm{km}) \\
\text { range (mean } \pm \mathrm{SE})\end{array}$ \\
\hline Juruena River (Brazil) & 5 & $\begin{array}{l}\text { Juruena and Tapajós main rivers; } \\
\text { confluences: Juruena River } \\
\text { with Cururu and Teles Pires rivers }\end{array}$ & $\begin{array}{c}7.5-69.9 \\
(25.6 \pm 11.6)\end{array}$ & $\begin{array}{c}0.070 .26 \\
(0.14 \pm 0.03)\end{array}$ \\
\hline San Martín River (Bolivia) & 4 & $\begin{array}{l}\text { San Martín main river; confluences: } \\
\text { San Joaquin River and clearwater } \\
\text { floodplain }\end{array}$ & $\begin{array}{c}93.6-297.9 \\
(160.8 \pm 47.3)\end{array}$ & $\begin{array}{c}0.4-3.9 \\
(1.6 \pm 0.79)\end{array}$ \\
\hline Amazon River (Colombia) & 2 & $\begin{array}{l}\text { Amazon and Loretoyacu main rivers; } \\
\text { confluences: Amazon River with } \\
\text { Loretoyacu and Atacuari rivers and } \\
\text { the Zaragoza creek, and Tarapoto } \\
\text { lagoons complex }\end{array}$ & $\begin{array}{c}33.1-36.2 \\
(34.6 \pm 1.5)\end{array}$ & $\begin{array}{c}0.25-0.35 \\
(0.30 \pm 0.05)\end{array}$ \\
\hline Orinoco River (Orinoco) & 4 & $\begin{array}{l}\text { Orinoco main river; confluences: } \\
\text { Bita and Meta rivers and the } \\
\text { Tesoro and Negro creeks }\end{array}$ & $\begin{array}{c}11.3-51.8 \\
(25.6 \pm 9.3)\end{array}$ & $\begin{array}{c}0.25-0.9 \\
(0.52 \pm 0.13)\end{array}$ \\
\hline Marañón River (Peru) & 8 & $\begin{array}{l}\text { Marañón main river; confluence: } \\
\text { Ucayali and Tigre rivers }\end{array}$ & $\begin{array}{c}9.5-91.8 \\
(48.2 \pm 10.5)\end{array}$ & $\begin{array}{c}0.06-1.5 \\
(0.75 \pm 0.16)\end{array}$ \\
\hline
\end{tabular}

distance covered by 1 individual was $225 \mathrm{~km}$. Their data were derived from 53 VHF radio-tagged adult individuals in the Japurá and Solimões rivers (Mamirauá Sustainable Development Reserve, Brazil) between 1994 and 1999. These authors verified the presence of resident and migrant individuals within the same population. Our results also agree with distance values reported from photo identification assessments (based on individual marks) by McGuire \& Henningsen (2007) at the Pacaya-Samiria Reserve in Peru (maximum 220 km, mean 60.8 km), and Denkinger (2010) in the Cuyabeno and Lagartococha rivers (Cuyabeno Reserve, Ecuador), where the maximum distances traveled by Inia geoffrensis geoffrensis individuals ranged from 50 to $200 \mathrm{~km}$.

Amazon river dolphins are one of the largest predators in the Amazon (Goulding et al. 1988, 2003, McGuire \& Winemiller 1998, Gómez-Salazar et al. 2012c), contributing to fish community structure (Lowe-McConnell 1975, 1987). The diets of river dolphins include fish of different sizes $(25-90 \mathrm{~cm})$, belonging to more than 43 species and at least 19 families, many of which show migratory patterns influenced by flood pulses (da Silva 1983, Best \& da Silva 1989). Long fish migrations from $500 \mathrm{~km}$ up to $3000 \mathrm{~km}$ (Zapata \& Usma 2013, Duponchelle et al. 2016, Barthem et al. 2017, Hauser et al. 2018) can potentially explain the relatively long distance values recorded by tagged dolphins in our study. This aspect requires further analyses, comparing satellite tracking data from both Amazon river dolphins and their fish prey within the same temporal window.
Previous studies have pointed out the different use of heterogenous habitat by river dolphins (McGuire \& Winemiller 1998, Martin \& da Silva 1998, 2004a,b, Trujillo 2000, McGuire \& Henningsen 2007, Denkinger 2010, Gómez-Salazar et al. 2012c, Mintzer et al. 2016). Trujillo $(1994,2000)$ and Trujillo \& MoralesBetancourt (2009) reported seasonal lateral and longitudinal movements based on direct sightings and photo identification and suggested that these movements were influenced by the reproductive processes associated with low water periods (June to September in the Amazon River basin and December to April in the Orinoco River basin). Amazon river dolphins have adapted their foraging and reproductive behavior (mating and care of their calves) to the flood pulse, which determines habitat and prey availability within both the Amazon and Orinoco river basins (Martin \& da Silva 2004b, Mintzer et al. 2016).

\subsection{Home range}

The kernel density estimator is considered to be one of the best methods for conducting spatial analyses on small cetaceans (Seaman \& Powell 1996, Seaman et al. 1999, Powell 2000, Flores \& Bazzalo 2004, Oshima et al. 2010). It has been applied to the study of home ranges, core areas, and movement patterns of harbor porpoises (Sveegaard et al. 2011), Hector's dolphins (Rayment et al. 2009), common bottlenose dolphins (Gubbins 2002, Wells et al. 2017, Balmer et al. 2019), and Guiana dolphins (Flores \& Bazzalo 


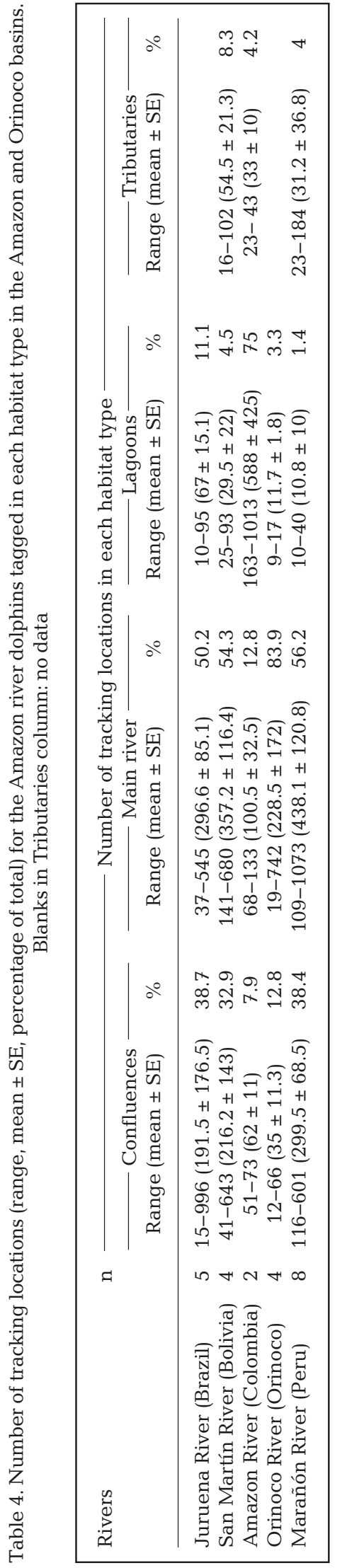

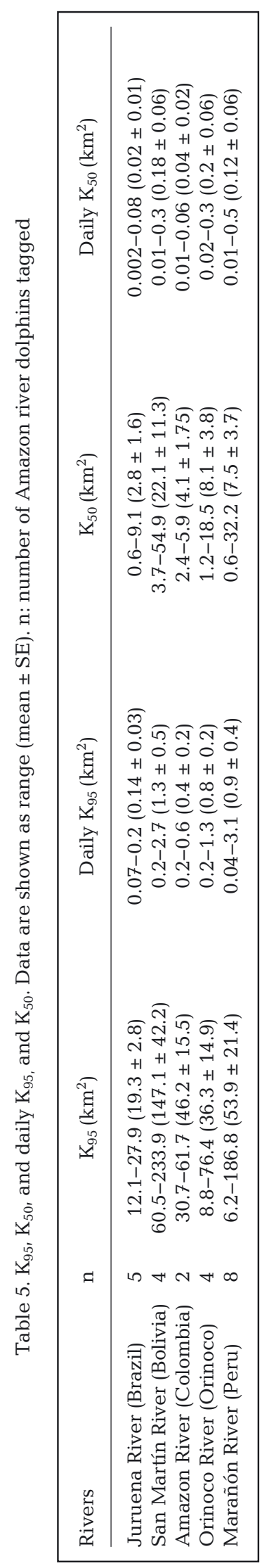

2004, Oshima et al. 2010). These are all coastal species with home ranges reported in square kilometers. Because of the linearity of rivers, the spatial use of the water courses for riverine cetacean species has been reported in the literature using linear units $(\mathrm{km})$ (Martin \& da Silva 1998, 2004b, McGuire \& Henningsen 2007, Denkinger 2010). A kernel analysis (KDE), as implemented in this study, allowed the calculation of the Inia home range areas in square kilometers (Table 2).

As already mentioned, home range as a spatial variable of dolphin ecology is determined by habitat heterogeneity, prey distribution, and dolphin foraging strategy; and these can be also influenced by physiological and ecological parameters, including social structure, reproductive status, and territoriality (Scott et al. 1990, Martin \& da Silva 1998, Defran et al. 1999, Gubbins 2002, Mesnick \& Ralls 2002, Flores \& Bazzalo 2004, Martin \& da Silva 2004b, Rayment 2009).

Elwen et al. (2006) noted that the relationship between body size and home range in odontocetes seems to break down in interspecies comparisons, and they suggest that ecological features and habitat types were the determining factors for home range size in different populations of dusky dolphins Lagenorhynchus obscurus.

Finally, it is important to mention that one of the major limitations of satellite tracking studies is the duration of the tag battery (Wells et al. 2017). In our study, we obtained a mean satellite tracking period of $107 \mathrm{~d}( \pm 15.7)$ for 23 individuals. This does not cover a full annual hydrologic cycle. This means that our home range values should be considered a minimum. It also limited inferences about the temporal and ecological determinants affecting home range values. In addition, the heterogeneity in tag transmission times (24 to $336 \mathrm{~d}$ ) introduced statistical difficulties when comparing the various sampling localities.

Based on our experience, we recommend (1) an increase in the number of tracked individuals for each aquatic system and (2) implementing a recapture procedure to exchange transmitters when the battery charge is low.

\subsection{Effect of tagging}

No fatal or injurious impacts or negative behavioral effects (such as erratic movements) were recorded among the 23 satellite-tagged individuals. Tag installation procedures followed established and approved recommendations for the SPOT-299A and 

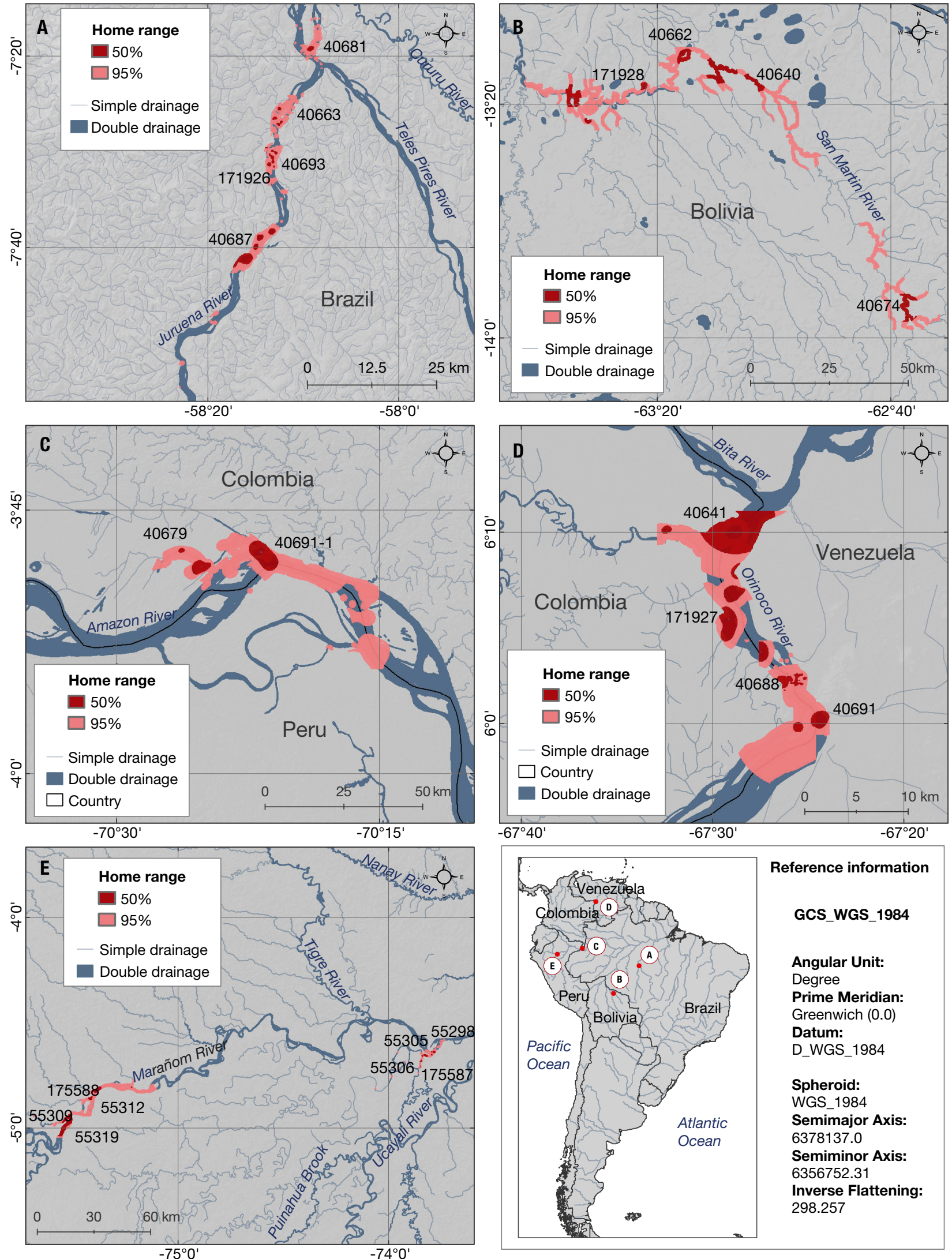

Fig. 2. Overall home range (95\%) and core area of activity (50\%) estimated using $\mathrm{K}_{95}$ and $\mathrm{K}_{50}$ utilization distribution (UD), respectively, for the 23 Amazon river dolphins tagged in the Amazon and Orinoco basins. Rivers: (A) Juruena, Brazil, (B) San Martín, Bolivia, (C) Amazon, Colombia, (D) Orinoco, Colombia, and (E) Marañón, Peru 
SPOT6-F transmitters, including a single anchor point to the river dolphin's dorsal fin. The selected transmitter was one of the lightest devices on the market (62 g) and was fitted to the dorsal fin with a self-release mechanism. The manufacturer assured us that the transmitter would be released from the dolphin's fin no more than 13 mo after it was fitted in place.

Some individuals were seen by researchers and Colombian fishermen who participated in this study after the tag was released and they reported complete healing of the pierced area. These observations are consistent with those of Martin et al. (2006), who followed 38 radio-tagged dolphins in the Mamirauá Reserve in Brazil for more than 10 yr.

\subsection{Implications for conservation}

Our results highlight the complexity of dolphin habitat requirements, an aspect that makes these organisms especially vulnerable to basin-scale transformations. The extinction of the baiji Lipotes vexillifer in the Yangtze River, China, raises concerns about the potential impacts of large-scale infrastructure projects, as well as fishery bycatch (Reeves et al. 2003, Turvey et al. 2007, Trujillo et al. 2010). Our documentation of movements across the Colombian and Peruvian border $(36.2 \mathrm{~km})$ in the Amazon River and between Colombia and Venezuela $(51.8 \mathrm{~km})$ in the Orinoco River basin demonstrates the need to initiate transboundary conservation strategies. Range countries of river dolphins in South America that have been analyzed have different regulations in crucial aspects such as: (1) the use of fishing gear; (2) closure periods for fish capture and trade; and (3) conservation strategies for threatened aquatic vertebrates. These differences demand a more coordinated transboundary conservation approach (Trujillo et al. 2010).

Our results also indicate that Amazon river dolphins use a diverse range of aquatic ecosystems in at least 7 protected areas in 4 countries. It is important to mention that I. geoffrensis is not currently included as a priority species in any of these protected areas, except for the Parque Departamental, Area Natural de Manejo Integrado (ANMI) Iténez, Bolivia (Trujillo et al. 2010, Mosquera-Guerra et al. 2018).

\section{CONCLUSIONS}

The design of conservation strategies for Amazon river dolphins should consider the large heterogeneity of ecosystems in the Amazon and the Orinoco river basins and the different use of habitat types by dolphins, including main rivers, confluences, tributaries, and lakes. Reported minimum home ranges are extensive and include the use of protected areas and Ramsar sites. Long-distance transboundary movements were documented between Colombia and Peru in the Amazon, and Colombia and Venezuela in the Orinoco basin. Our results suggest that, to ensure that habitat requirements are met, transboundary management policies should be designed to prioritize the ecological integrity and connectivity of aquatic ecosystems used by river dolphins.

Acknowledgements. This program is part of the strategic plan set by the South American River Dolphin Initiative (SARDI), supported by World Wildlife Fund (WWF) in Brazil, Colombia, Peru, Ecuador, and Bolivia. Partial support for 2 tags in Peru was provided by the Rufford Foundation through RSG. Special gratitude to D. Amorocho, D. Willems, K. Berg, L. Sainz, J. Rivas, J. Surkin, R. Maldonado, D. Ember, V. Tellez, H. Yagui, N. Acuña, P. Colchao, M. Pajuelo, F. Nishio, and M. Wulms from WWF, and D. Parks from the Whitley Fund for Nature (WFN). F.M.G. received a doctoral scholarship from Colciencias (National Doctorate Scholarship 785 to 2017). E.C. received a doctoral scholarship from WWF-EFN. A. Echeverría and A. Salinas are acknowledged for their support during tagging campaigns in Bolivia. We acknowledge the fishing communities and the local and national authorities for participating in the river dolphin capture process.

\section{LITERATURE CITED}

Aliaga-Rossel E (2002) Distribution and abundance of the pink river dolphin, bufeo (Inia geoffrensis) in the Tijamuchi River, Beni-Bolivia. Aquat Mamm 28:312-323

Aliaga-Rossel E, Guizada Duran LA (2020) Four decades of research on distribution and abundance of the Bolivian river dolphin Inia geoffrensis boliviensis. Endang Species Res 42:151-165

Aliaga-Rossel E, McGuire TL, Hamilton H (2006) Distribution and encounter rates of the river dolphin (Inia geoffrensis boliviensis) in the central Bolivian Amazon. J Cetacean Res Manag 8:87-92

Almeida RM, Hamilton SK, Rosi EJ, Barros N and others (2020) Hydropeaking operations of two run-of-river mega-dams alter downstream hydrology of the largest Amazon tributary. Front Environ Sci 8:120

Anderson EP, Jenkins CN, Heilpern S, Maldonado-Ocampo JA and others (2018) Fragmentation of Andes-to-Amazon connectivity by hydropower dams. Science Adv 4: eaao1642

Azevedo AF, Oliveira AM, Viana SC, Sluys MV (2007) Habitat use by marine tucuxis (Sotalia guianensis) (Cetacea: Delphinidae) in Guanabara Bay, south-eastern Brazil. J Mar Biol Assoc UK 87:201-205

Ballance LT (1992) Habitat use patterns and ranges of the bottlenose dolphin in the Gulf of California, Mexico. Mar Mamm Sci 8:262-274

Balmer BC, Wells RS, Schwacke LH, Rowles TK and others (2011) Evaluation of a single-pin, satellite-linked transmitter deployed on bottlenose dolphins (Tursiops trunca- 
tus) along the coast of Georgia, USA. Aquat Mamm 37: 187-192

Balmer BC, Wells RS, Howle LE, Barleycorn AA and others (2014) Advances in cetacean telemetry: a review of single-pin transmitter attachment techniques on small cetaceans. Mar Mamm Sci 30:656-673

Balmer BC, Zolman E, Bolton J, Fauquier D and others (2019) Ranging patterns and exposure to cumulative stressors of a Tursiops truncatus (common bottlenose dolphin) in Georgia. Notes Southeast Nat 18:N1-N9

Barthem RB, Goulding M, Leite RG, Cañas C and others (2017) Goliath catfish spawning in the far western Amazon confirmed by the distribution of mature adults, drifting larvae and migrating juveniles. Sci Rep 7:41784

Best RC, da Silva VMF (1989) Amazon River dolphin, boto Inia geoffrensis (de Blainville, 1817). In: Ridgway $\mathrm{SH}$, Harrison R (eds) Handbook of marine mammals, Vol 4: River dolphins and the larger toothed whales, Academic Press, London, p 1-24

Bordino P, Wells RS, Stamper MA (2008) Satellite tracking of franciscana dolphins Pontoporia blainvillei in Argentina: preliminary information on ranging, diving and social patterns. International Whaling Commission Scientific Committee Meeting, Santiago, June 2008, SC60/SM14

CLS (Collecte Localisation Satellites) (2011) Argos user's manual. Collecte Localization Satellites, RamonvilleSaint-Agne

Copernicus Sentinel (2020) The Copernicus Open Access Hub. https://scihub.copernicus.eu/ (accessed on 3 March 2020)

da Silva VMF (1983) Ecologia alimentar dos golfinhos da Amazônia. MSc thesis, Fundação Universidade do Amazonas, Manaus

da Silva VMF (2002) Amazon river dolphin Inia geoffrensis. In: Perrin WF, Würsig B, Thewissen JGM (eds) Encyclopedia of marine mammals. Academic Press, San Diego, p 18-20

da Silva VMF (2009) Amazon river dolphin: Inia geoffrensis, 2nd edn. In: Perrin WF, Würsig B, Thewissen JGM (eds) Encyclopedia of marine mammals. Academic Press, London, p 26-28

da Silva V, Trujillo F, Martin A, Zerbini AN, Crespo E, AliagaRossel E, Reeves R (2018) Inia geoffrensis. The IUCN Red List of Threatened Species. www.iucnredlist.org (accessed 1 February 2020). https://dx.doi.org/10.2305/IUCN. UK.2018-2.RLTS.T10831A50358152.en

* Defran RH, Weller DW, Kelly DL, Espinosa MA (1999) Range characteristics of Pacific Coast bottlenose dolphins (Tursiops truncatus) in the Southern California bight. Mar Mamm Sci 15:381-393

Denkinger J (2010) Population density, abundance estimates, habitat preference and social structure of Amazon river dolphins (Inia geoffrensis) in Cuyabeno Reserve, Ecuador. Av Cienc Ing 2:B91-B97

* Dixon KR, Chapman JA (1980) Harmonic mean measure of animal activity areas. Ecology 61:1040-1044

Dolton HR, Gell FR, Hall J, Hall G, Hawkes LA, Witt MJ (2020) Assessing the importance of Isle of Man waters for the basking shark Cetorhinus maximus. Endang Species Res 41:209-223

* Duponchelle F, Pouilly M, Pécheyran C, Hauser M and others (2016) Trans-Amazonian natal homing in giant catfish. J Appl Ecol 53:1511-1520

Elwen S, Meÿer MA, Best PB, Kotze PGH, Thornton M, Swanson S (2006) Range and movements of female
Heaviside's dolphins (Cephalorhynchus heavisidii), as determined by satellite-linked telemetry. J Mammal 87: 866-877

ESRI (Environmental Systems Research Institute) (2014) ArcGIS Desktop: Release 10.2.x. Environmental Systems Research Institute, Redlands, CA

Flores PAC, Bazzalo M (2004) Home range and movement patterns of the marine tucuxi dolphin, Sotalia fluviatilis, in Baia Norte, Southern Brazil. Lat Am J Aquat Mamm 3: $37-52$

Forsberg BR, Melack JM, Dunne T, Barthem RB and others (2017) The potential impact of new Andean dams on Amazon fluvial ecosystems. PLOS ONE 12:e0182254

Gómez-Salazar C, Trujillo F, Portocarrero-Aya M, Whitehead H (2012a) Population, density estimates, and conservation of river dolphins (Inia and Sotalia) in the Amazon and Orinoco river basins. Mar Mamm Sci 28:124-153

Gómez-Salazar C, Trujillo F, Whitehead H (2012b) Ecological factors influencing group sizes of river dolphins (Inia geoffrensis and Sotalia fluviatilis). Mar Mamm Sci 28: E124-E142

* Gómez-Salazar C, Coll M, Whitehead H (2012c) River dolphins as indicators of ecosystem degradation in large tropical rivers. Ecol Indic 23:19-26

Goulding M, Carvalho ML, Ferreira EG (1988) Rio Negro: rich life in poor water. SPB Academic Publishing, The Hague

Goulding M, Barthem RB, Ferreira EJG (2003) The Smithsonian atlas of the Amazon. Smithsonian Institution Press, Washington, DC

Gravena W, Farias IP, da Silva MNF, da Silva VMF, Hrbek T (2014) Looking to the past and the future: Were the Madeira River rapids a geographical barrier to the boto (Cetacea: Iniidae)? Conserv Genet 15:619-629

* Gravena W, da Silva VMF, da Silva MNF, Farias IP, Hrbek T (2015) Living between rapids: genetic structure and hybridization in botos (Cetacea: Iniidae: Inia spp.) of the Madeira River, Brazil. Biol J Linn Soc 114:764-777

Gubbins C (2002) Use of home ranges by resident bottlenose dolphins (Tursiops truncatus) in a South Carolina estuary. J Mammal 83:178-187

Harestad AS, Bunnel FL (1979) Home range and body weight - a reevaluation. Ecology 60:389-402

*Hauser M, Doria CRC, Melo LRC, Santos AR and others (2018) Age and growth of the Amazonian migratory catfish Brachyplatystoma rousseauxii in the Madeira river basin before the construction of dams. Neotrop Ichthyol 16:e170130

* Hemson G, Johnson P, South A, Kenward R, Ripley R, MacDonald D (2005) Are kernels the mustard? Data from global positioning system (GPS) collars suggests problems for kernel home-range analyses with least-squares cross-validation. J Anim Ecol 74:455-463

Herrera O, Ferrer A, Boede E, Trujillo F and others (2017) Tonina del Orinoco Inia geoffrensis (Blainville, 1817). In: Ferrer A, Herrera O, Trujillo F, Mosquera-Guerra F and others (eds) Plan de acción para la conservación de los mamíferos acuáticos de Venezuela: delfines de agua dulce, nutrias y manatíes 2017-2027. Caracas, Venezuela, p 12-17

Hoorn C, Wesselingh FP (2010) Amazonia: landscape and species evolution: a look into the past. Blackwell Publishing, Chichester

Ingram SM, Rogan E (2002) Identifying critical areas and habitat preferences of bottlenose dolphins Tursiops truncatus. Mar Ecol Prog Ser 244:247-255 
Junk WJ, Furch K (1993) A general review of tropical South American floodplains. Wetlands Ecol Manage 2:231-238

Kenward RE (2001) A manual for wildlife radio tagging. Academic Press, San Diego

Latrubesse EM, Arima EY, Dunne T, Park E and others (2017) Damming the rivers of the Amazon basin. Nature 546:363-369

Lowe-McConnell H (1975) Fish communities in tropical freshwaters. Longman, London

Lowe-McConnell H (1987) Ecological studies in tropical fish communities. Cambridge University Press, Cambridge

MacLeod C (2013) An introduction to using GIS in marine biology: investigating home ranges of individual animals (supplementary workbook 4). Pictish Beast Publications, Glasgow

Martin AR, da Silva VMF (1998) Tracking aquatic vertebrates in dense tropical forest using VHF telemetry. Mar Technol Soc J 32:82-88

Martin AR, da Silva VMF (2004a) Number, seasonal movements, and residency characteristics of river dolphins in an Amazonian floodplain lake system. Can J Zool 82: $1307-1315$

Martin AR, da Silva VMF (2004b) River dolphins and flooded forest: seasonal habitat use and sexual segregation of botos (Inia geoffrensis) in an extreme cetacean environment. J Zool (Lond) 263:295-305

* Martin AR, da Silva VMF (2018) Reproductive parameters of the Amazon river dolphin or boto, Inia geoffrensis (Cetacea: Iniidae); an evolutionary outlier bucks no trends. Biol J Linn Soc 123:666-676

Martin AR, da Silva VMF, Rothery PR (2006) Does radio tagging affect the survival or reproduction of small cetaceans? A test. Mar Mamm Sci 22:17-24

McGuire TL, Henningsen T (2007) Movement patterns and site fidelity of river dolphins (Inia geoffrensis and Sotalia fluviatilis) in the Peruvian Amazon as determined by photo-identification. Aquat Mamm 33:359-367

McGuire TL, Winemiller K (1998) Occurrence patterns, habitat associations, and potential prey of the river dolphin, Inia geoffrensis, in the Cinaruco River, Venezuela. Biotropica 30:625-638

Mesnick SL, Ralls K (2002) Mating systems. In: Perrin WF, Würsig B, Thewissen JGM (eds) Encyclopedia of marine mammals. Academic Press, San Diego, CA, p 726-733

Mintzer VJ, Lorenzen K, Frazer TK, da Silva VMF, Martin AR (2016) Seasonal movements of river dolphins (Inia geoffrensis) in a protected Amazonian floodplain. Mar Mamm Sci 32:664-681

Mosquera-Guerra F, Parra C, Trujillo F, Jiménez-Ortega AM, Mantilla-Meluk M (2015) Valoración estacional de las amenazas contra la conservación de Inia geoffrensis humboldltiana (Cetartiodactyla Iniidae) en la cuenca del Río Meta, Colombia. Therya 6:371-388

Mosquera-Guerra F, Trujillo F, Parks D, Oliveira-da-Costa $\mathrm{M}$ and others (2018) Analysis of distribution of river dolphins (Inia and Sotalia) in protected and transformed areas in the Amazon and Orinoco basins. International Whaling Commission Scientific Committee SC/67B/ $\mathrm{SM} / 16$

* Mosquera-Guerra F, Trujillo F, Parks D, Oliveira da Costa M and others (2019) Mercury in populations of river dolphins of the Amazon and Orinoco basins. EcoHealth 16: 743-758

Mosquera-Guerra F, Trujillo F, Aya-Cuero CA, Franco-León $\mathrm{N}$ and others (2020) Population estimate and identifica- tion of major conservation threats for the river dolphin (Inia geoffrensis humboldtiana) at the Colombian Orinoquia. Therya 11:9-21

* Oshima JEDF, Oliveira Santos MCD, Bazzalo M, Carvalho Flores PAD, Nascimento Pupim FD (2010) Home ranges of Guiana dolphins (Sotalia guianensis) (Cetacea: Delphinidae) in the Cananeia estuary, Brazil. J Mar Biol Assoc UK 90:1641-1647

* Ostfeld RS (1990) The ecology of territoriality in small mammals. Trends Ecol Evol 5:411-415

Ouellette M, Cardille A (2011) The complex linear home range estimator: representing the home range of river turtles moving in multiple channels. Chelonian Conserv Biol 10:259-265

* Pavanato H, Melo-Santos G, Lima DS, Portocarrero-Aya M and others (2016) Risk of dam construction for South American river dolphins: a case of study of the Tapajós River. Endang Species Res 31:47-60

Powell RA (2000) Animal home ranges and territories and home range estimators. In: Boitani L, Fuller TK (eds) Research and techniques in animal ecology: controversies and consequences. Columbia University Press, New York, NY, p 65-110

R Core Team (2017) R: a language and environment for statistical computing. R Foundation for Statistical Computing, Vienna

R Studio Team (2014) RStudio: integrated development for R. RStudio, Boston, MA

Rayment W, Dawson S, Slooten E, Bräger S, Du Fresne S, Webster T (2009) Kernel density estimates of alongshore home range of Hector's dolphins at Banks Peninsula, New Zealand. Mar Mamm Sci 25:537-556

Reeves RR, Smith B, Crespo EA, Notarbartolo Di Sciara G (eds) (2003) Dolphins, whales and porpoises. 2002-2010 Conservation Action Plan for the World's Cetaceans. IUCN/SSC Cetacean Specialist Group, Gland

Rossi-Santos MR, Wedekin LL, Sousa-Lima RS (2006) Distribution and habitat use of small cetaceans off Abrolhos Bank, eastern Brazil. Lat Am J Aquat Mamm 5:23-28

* Samuel MD, Pierce DJ, Garton EO (1985) Identifying areas of concentrated use within the home range. J Anim Ecol 54:711-719

Scott MD, Wells RS, Irvine AB (1990) A long-term study of bottlenose dolphins on the west coast of Florida. In: Leatherwood S, Reeves RS (eds) The bottlenose dolphin. Academic Press, San Diego, CA, p 235-244

* Seaman DE, Powell RA (1996) An evaluation of the accuracy of kernel density estimators for home range analysis. Ecology 77:2075-2085

* Seaman DE, Millspaugh JJ, Kernohan BJ, Brundige GC, Raedeke KJ, Gitzen RA (1999) Effects of sample size on kernel home range estimates. J Wildl Manag 63:739-747

* Seminoff JA, Resendiz A, Nichols WJ (2002) Home range of green turtles Chelonia mydas at a coastal foraging area in the Gulf of California, Mexico. Mar Ecol Prog Ser 242: 253-265

Sioli H (1984) The Amazon and its main affluents: hydrography, morphology of the river courses, and river types. In: Sioli H (ed) The Amazon: limnology and landscape ecology of a mighty tropical river and its basin. Dr. W. Junk Publishers, Dordrecht, p 127-166

* Sveegaard S, Teilmann J, Tougaard J, Dietz R, Mouritsen KN, Desportes G, Siebert U (2011) High-density areas for harbor porpoises (Phocoena phocoena) identified by satellite tracking. Mar Mamm Sci 27:230-246 
Swihart RK, Slade NA, Bergstrom B (1988) Relating body size to the rate of home range use in mammals. Ecology 69:393-399

Trujillo F (1994) The use of photo-identification to study the Amazon river dolphin, Inia geoffrenis, in the Colombian Amazon. Mar Mamm Sci 10:348-353

Trujillo F (2000) Habitat use and social behavior of the freshwater dolphin Inia geoffrensis (de Blainville 1817) in the Amazon and Orinoco basins. PhD thesis. Aberdeen University

Trujillo F, Morales Betancourt D (2009) Mamíferos dulceacuícolas migratorios en Colombia. In: Amaya Espinel JD, Zapata Padilla LA (eds) Plan Nacional de las especies migratorias. Diagnóstico e identificación de acciones para la conservación y el manejo sostenible de las especies migratorias de la biodiversidad en Colombia. Ministerio de Ambiente, WWF, Bogotá, D.C., p 41-49

Trujillo F, Crespo E, van Damme P, Usma JS (2010) The action plan for South American river dolphins 2010-2020. WWF, Fundación Omacha, WCS, WDCS, SOLAMAC, Bogotá, D.C.

*Trujillo F, Mosquera F, Franco N (2019) Delfines de Río: Especies indicadores del estado de salud en los ecosistemas acuáticos de la Amazonia y Orinoquia. Rev Acad Colomb Cienc Exactas Fis Nat 43:199-211

Turvey ST, Pitman RL, Taylor BL, Barlow J and others (2007) First human-caused extinction of a cetacean species? Biol Lett 3:537-540

Wedekin LL, Daura-Jorge FG, Piacentini VQ, Simoes-Lopes PC (2007) Seasonal variations in spatial usage by the estuarine dolphin, Sotalia guianensis (van Beneden,

Editorial responsibility: Sascha Hooker,

St. Andrews, UK

Reviewed by: B. Smith and 1 anonymous referee
1864) (Cetacea; Delphinidae) at its southern limit of distribution. Braz J Biol 67:1-8

Wells RS (1991) The role of long-term study in understanding the social structure of a bottlenose dolphin community. In: Pryor K, Norris KS (eds) Dolphin societies: discoveries and puzzles. University of California Press, Berkeley, p 199-225

Wells RS, McHugh KA, Douglas DC, Shippee S, McCabe EJB, Barros NB, Phillips GT (2013) Evaluation of potential protective factors against metabolic syndrome in bottlenose dolphins: feeding and activity patterns of dolphins in Sarasota Bay, Florida. Front Endocrinol 4: $1-16$

Wells RS, Schwacke LH, Rowles TK, Balmer BC and others (2017) Ranging patterns of common bottlenose dolphins Tursiops truncatus in Barataria Bay, Louisiana, following the Deepwater Horizon oil spill. Endang Species Res 33: $159-180$

White GC, Garrott RA (1990) Analysis of wildlife radiotracking data. Academic Press, San Diego, CA

*Witt MJ, Åkesson S, Broderick AC, Coyne MS and others (2010) Assessing accuracy and utility of satellite-tracking data using Argos-linked Fastloc-GPS. Anim Behav 80: 571-581

* Worton BJ (1989) Kernel methods for estimating the utilization distribution in home-range studies. Ecology 70: 164-168

Zapata LA, Usma JS (2013) Guía de las especies migratorias de la biodiversidad en Colombia. Peces. Ministerio de Ambiente y Desarrollo Sostenible, WWF-Colombia, Bogotá, D.C.

Submitted: October 10, 2019

Accepted: May 11, 2021

Proofs received from author(s): July 19, 2021 